\title{
Design, Synthesis, and Functional Analysis of Highly Specific Artificial Small RNAs with Antiviral Activity in Plants
}

\author{
Alberto Carbonell and José-Antonio Daròs
}

\begin{abstract}
Artificial microRNAs (amiRNAs) and synthetic trans-acting small interfering RNAs (syn-tasiRNAs) are two classes of artificial small RNAs (sRNAs) that have been broadly used to confer antiviral resistance in plants. However, methods for designing, synthesizing and functionally analyzing antiviral artificial sRNAs have not been optimized for time and cost-effectiveness and high-throughput applicability since recently. Here we present a systematic methodology for the simple and fast-forward design, generation, and functional analysis of large numbers of artificial sRNA constructs engineered to induce high levels of antiviral resistance in plants. Artificial sRNA constructs are transiently expressed in Nicotiana benthamiana plants, which are subsequently inoculated with the virus of interest. The antiviral activity of each artificial sRNA construct is assessed by monitoring viral symptom appearance, and through molecular analysis of virus accumulation in plant tissues. This approach is aimed to easily identify artificial sRNAs with high antiviral activity that could be expressed in transgenic plants for highly durable antiviral resistance.
\end{abstract}

Key words Plant virus, Antiviral resistance, Artificial small RNAs, AmiRNAs, Syn-tasiRNAs

\section{Introduction}

Artificial microRNAs (amiRNAs) and synthetic trans-acting small interfering RNAs (syn-tasiRNAs) are two classes of artificial small RNAs (sRNAs) engineered to selectively silence transcripts in plants, including viral RNAs [1]. AmiRNAs and syn-tasiRNAs are produced in planta by expressing a functional miRNA or tasiRNA precursor with modified miRNA or tasiRNA sequences, respectively. AmiRNAs are generated from DICER-LIKEl (DCLl) cleavage of precursors with foldback structures, while syn-tasiRNAs are produced after cleavage of a TAS precursor by an miRNA/ ARGONAUTE (AGO) complex, RNA-DEPENDENT RNA POLYMERASE 6 conversion of one of the cleavage products to 
double-stranded RNA, and DLC4-mediated processing of the dsRNA into 21-nucleotide phased syn-tasiRNAs in register with the miRNA-guided cleavage site. Despite their biogenesis pathways are different, both classes of artificial sRNAs associate with an AGO protein, generally AGOl, to target and cleave highly sequence complementary transcripts [2].

AmiRNAs have been extensively used to selectively confer antiviral resistance in transgenic plants [3]. However, because antiviral amiRNAs typically target a single viral RNA site, this resistance can be overcome if virus variants accumulate mutations in the amiRNA target site $[4,5]$. To avoid these limitations, multiple amiRNAs have been expressed from different precursors or from a single polycistronic precursor to target several regions within a single viral RNA [6-9]. Syn-tasiRNAs have recently emerged as an alternative to amiRNA to induce antiviral resistance in plants. This is another possibility of expressing multiple artificial sRNAs from a single precursor, which should also allow the targeting of multiple sites within a viral RNA or of multiple sequence unrelated viruses, and therefore could induce more durable antiviral resistance [10]. Indeed, syn-tasiRNAs have already been reported to induce simultaneous resistance to two different viruses [11], and to interfere with viroid infections as well [12].

Despite both classes of artificial sRNAs have been used to confer antiviral resistance, methods for designing, synthesizing and functionally analyzing artificial sRNAs have not been optimized for time and cost-effectiveness and high-throughput applicability since recently [13-15]. In this chapter, we describe a detailed methodology for the automated design, high-throughput generation and functional analysis of large number of artificial sRNA constructs with antiviral activity in plants. First, we detail the design process of highly specific antiviral amiRNAs with the P-SAMS ("Plant Small RNA Maker Suite") web tool [15] and the molecular methods for their cloning into $B s a \mathrm{I} / c c d \mathrm{~B}$ " $\mathrm{B} / \mathrm{c}$ " vectors, a recently reported new generation of amiRNA vectors for efficient gene silencing in plants $[13,14]$. Next, the experimental plan to analyze the antiviral activity of large numbers of amiRNA constructs is described. AmiRNA constructs are transiently expressed in Nicotiana benthamiana plants, which are subsequently inoculated with the virus of interest. The antiviral activity of each amiRNA construct is assessed by monitoring viral symptoms, and through molecular analysis of virus accumulation in plant tissues. Finally, we describe the design, generation, and functional analysis of syntasiRNA constructs that include several artificial sRNA sequences with high antiviral activity, which were previously selected from the initial amiRNA screening. This methodology has been successfully applied to identify highly active artificial sRNAs against Potato spindle tuber viroid [12] and Tomato spotted wilt virus [16]. 


\section{Materials}

\subsection{Antiviral AmiRNA Design}

\subsection{Antiviral AmiRNA} Cloning
1. Computer with Internet connection.

2. Web browser (e.g., Google Chrome, Safari, Mozilla Firefox, Internet Explorer).

1. Oligo Annealing buffer: $60 \mathrm{mM}$ Tris- $\mathrm{HCl}$ (pH 7.5), $500 \mathrm{mM}$ $\mathrm{NaCl}, 60 \mathrm{mM} \mathrm{MgCl}$, $10 \mathrm{mM}$ DTT (see Note $\mathbf{1}$ ).

2. Thermocycler.

3. Water bath.

4. Sterile $\mathrm{H}_{2} \mathrm{O}$.

5. T4 DNA ligase $(5 \mathrm{U} / \mu \mathrm{L}$, Thermo Fisher Scientific).

6. BsaI (10 U/ $\mu \mathrm{L}$, New England Biolabs).

7. Competent cells of Escherichia coli (E. coli) $c c d \mathrm{~B}$-sensitive strain (e.g., DH5 $\alpha$, DH10B, TOP10).

8. LB agar plate with kanamycin: $10 \mathrm{~g} / \mathrm{L}$ tryptone, $5 \mathrm{~g} / \mathrm{L}$ yeast extract, $10 \mathrm{~g} / \mathrm{L} \mathrm{NaCl}, 15 \mathrm{~g} / \mathrm{L}$ of Bacto agar, and $50 \mathrm{mg} / \mathrm{L}$ of kanamycin.

9. Liquid LB with kanamycin: $10 \mathrm{~g} / \mathrm{L}$ tryptone, $5 \mathrm{~g} / \mathrm{L}$ yeast extract, $10 \mathrm{~g} / \mathrm{L} \mathrm{NaCl}$, and $50 \mathrm{mg} / \mathrm{L}$ of kanamycin.

10. GeneJET Plasmid Miniprep Kit (Thermo Fisher Scientific).

11. B/c vectors: Each vector contains a unique combination of bacterial and plant antibiotic resistance genes. Eudicot amiRNA $\mathrm{B} / \mathrm{c}$ vectors are $p E N T R-A t M I R 390 a-B / c$ (Addgene plasmid 51,778), pFK210B-AtMIR390a-B/c (Addgene plasmid 51,777), $p M D C 123 S B-A t M I R 390 a-B / c$ (Addgene plasmid 51,775) and $p M D C 32 B-A t M I R 390 a-B / c$ (Addgene plasmid 51,778$)$. Monocot amiRNA vectors are $p E N T R-$ OsMIR 390-B/c (Addgene plasmid 61,468), $p H 7 W G 2 B-$ OsMIR390-B/c (Addgene plasmid 61,465), pMDC123SB-OsMIR390-B/c (Addgene plasmid 61,466), and pMDC32B-OsMIR390-B/c (Addgene plasmid 61,467) $[13,14]$ (Table 1) ( see Note 2).

12. Oligonucleotides

\begin{tabular}{ll}
\hline Ml3-F: & CCCAGTCACGACGTTGTAAAACGACGG \\
M13-R: & CAGAGCTGCCAGGAAACAGCTATGACC \\
attB1: & ACAAGTTTGTACAAAAAAGCAGGCT \\
attB2: & ACCACTTTGTACAAGAAAGCTGGGT \\
\hline
\end{tabular}

13. Competent cells of Agrobacterium tumefaciens GV3101 strain. 


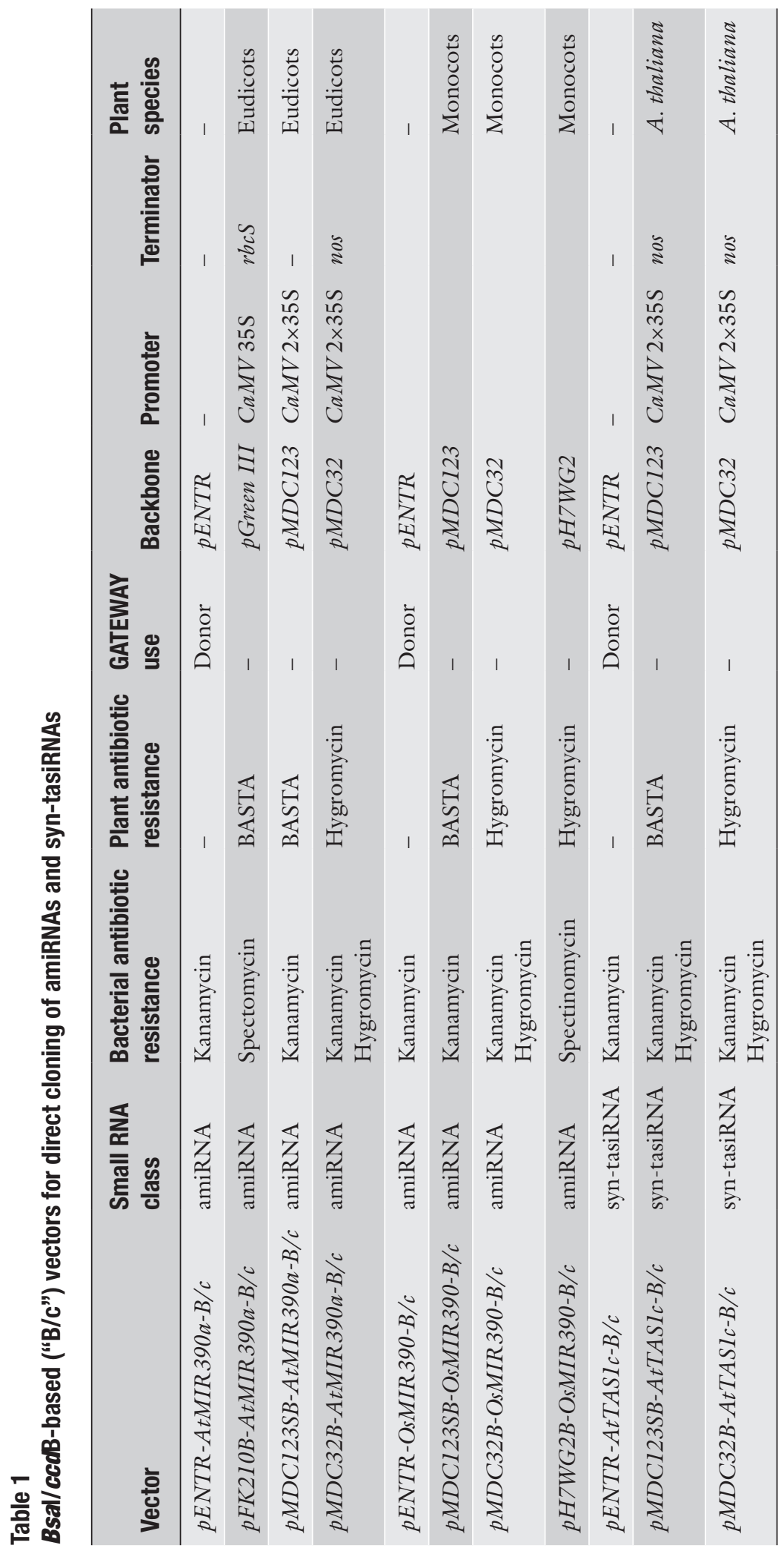




\subsection{Functional Analysis of Antiviral AmiRNAs}

2.3.1 Agroinfiltration in Nicotiana benthamiana

2.3.2 Analysis of Antiviral AmiRNA Accumulation

Total RNA Extraction

Northern Blot Analysis of AmiRNAs
1. Nicotiana benthamiana: 3-4-week-old N. benthamiana plants.

2. $\mathrm{LB}$ with antibiotics: $10 \mathrm{~g} / \mathrm{L}$ tryptone, $5 \mathrm{~g} / \mathrm{L}$ yeast extract, $10 \mathrm{~g} / \mathrm{L} \mathrm{NaCl}, 50 \mathrm{mg} / \mathrm{L}$ rifampicin, and $50 \mathrm{mg} / \mathrm{L}$ kanamycin.

3. Sterilized stock solutions: $1 \mathrm{M} \mathrm{MgSO}_{4}, 1 \mathrm{M} \mathrm{CaCl}_{2}, 20 \%$ glucose, $1 \mathrm{M}$ MES buffer ( $\mathrm{pH} 5.2$ ), and $0.1 \mathrm{M}$ acetosyringone.

4. M9 solution: $6 \mathrm{~g} / \mathrm{L}$ of $\mathrm{Na}_{2} \mathrm{HPO}_{4}, 3 \mathrm{~g} / \mathrm{L}$ of $\mathrm{KH}_{2} \mathrm{PO}_{4}, 0.5 \mathrm{~g} / \mathrm{L}$ $\mathrm{NaCl}$, and $1 \mathrm{~g} / \mathrm{L} \mathrm{NH}_{4} \mathrm{Cl}$. Adjust $\mathrm{pH}$ to 5.2 with $\mathrm{KOH}$ and autoclave. Add $2 \mathrm{~mL} 1 \mathrm{M} \mathrm{MgSO}_{4}, 0.1 \mathrm{~mL} 1 \mathrm{M} \mathrm{CaCl}_{2}$, and $10 \mathrm{~mL} \mathrm{20 \%} \mathrm{glucose} \mathrm{in} \mathrm{sterile} \mathrm{hood.}$

5. Vir Induction medium: Add $5 \mathrm{~mL} \mathrm{20 \%} \mathrm{glucose,} 5 \mathrm{~mL} 1 \mathrm{M}$ MES buffer ( $\mathrm{pH} 5.2$ ), $500 \mu \mathrm{L} 0.1 \mathrm{M}$ acetosyringone, $50 \mu \mathrm{L}$ $1 \mathrm{M} \mathrm{CaCl}_{2}$, and $1 \mathrm{~mL} 1 \mathrm{M} \mathrm{MgSO}_{4}$ to $500 \mathrm{~mL}$ of sterile M9 solution.

6. Infiltration solution: Add $5 \mathrm{~mL} 1 \mathrm{M} \mathrm{MgCl}_{2}, 5 \mathrm{~mL} 1 \mathrm{M}$ MES buffer ( $\mathrm{pH} 5.2$ ), and $750 \mu \mathrm{L} 0.1 \mathrm{M}$ acetosyringone to $500 \mathrm{~mL}$ of sterile $\mathrm{H}_{2} \mathrm{O}$.

7. $1 \mathrm{~mL}$ syringes without needles.

1. TRIzol reagent (Invitrogen).

2. Chloroform.

3. Isopropanol.

4. Cold $75 \%$ ethanol.

5. NanoDrop (Thermo Fisher Scientific).

1. $5 \times$ Tris-borate-EDTA (TBE): $54 \mathrm{~g} / \mathrm{L}$ Tris base, $27.5 \mathrm{~g} / \mathrm{L}$ boric acid, $20 \mathrm{~mL} 0.5 \mathrm{M}$ EDTA (pH 8.0).

2. $30 \%$ polyacrylamide (37.5:1): Dissolve $29.2 \mathrm{~g}$ acrylamide and $0.8 \mathrm{~g}$ bisacrylamide in $100 \mathrm{~mL} \mathrm{H}_{2} \mathrm{O}$.

3. Urea, electrophoresis grade.

4. TEMED: $N, N, N, N^{\prime}$-tetramethylethylenediamine.

5. Ammonium persulfate: $10 \%$ aqueous solution.

6. Formamide loading buffer: $95 \%$ formamide, $0.1 \%(\mathrm{w} / \mathrm{v})$ bromophenol blue, $0.1 \%(\mathrm{w} / \mathrm{v})$ xylene cyanol FF, $5 \mathrm{mM}$ EDTA (pH 8.0).

7. Gel plate, an electrophoresis apparatus, and a power supply.

8. Blotting paper.

9. Whatman Nytran SuperCharge nylon membrane (Sigma-Aldrich).

10. Semidry electroblotting apparatus.

11. UV cross-linker. 
2.3.3 Virus Inoculation

\subsection{Antiviral \\ Syn-tasiRNA Design}

2.5 Antiviral

Syn-tasiRNA Cloning

2.6 Functional Analysis of Antiviral Syn-tasiRNA
12. Probe oligonucleotide: DNA or LNA oligonucleotide complementary to the amiRNA to be analyzed.

13. T4 polynucleotide kinase.

14. $\left.{ }^{32} \mathrm{P}\right] \gamma$-ATP, $6000 \mathrm{Ci} / \mathrm{mmol}, 10 \mathrm{mCi} / \mathrm{mL}$

15. Mini Quick Spin Oligo Columns (Roche Life Science).

16. PerfectHyb ${ }^{\mathrm{TM}}$ Plus buffer (Sigma-Aldrich) or equivalent hybridization solution.

17. $20 \times$ SSC (saline sodium citrate): $3.0 \mathrm{M} \mathrm{NaCl}, 0.3 \mathrm{M}$ sodium citrate, $\mathrm{pH} 7.0$.

18. $10 \%$ SDS: $10 \%(\mathrm{w} / \mathrm{v})$ sodium dodecyl sulfate in sterile $\mathrm{H}_{2} \mathrm{O}$.

19. Wash buffer $1: 2 \times$ SSC, $0.1 \%$ SDS. Prepare with $20 \times$ SSC, $10 \%$ SDS solution, and sterile $\mathrm{H}_{2} \mathrm{O}$.

20. Wash buffer 2: $0.1 \times$ SSC, $0.1 \%$ SDS. Prepare with $20 \times$ SSC, $10 \%$ SDS solution, and sterile $\mathrm{H}_{2} \mathrm{O}$.

21. $3 \times$ SSC: Dilute $20 \times$ SSC with sterile $\mathrm{H}_{2} \mathrm{O}$.

1. Inoculation buffer: $50 \mathrm{mM}$ potassium phosphate $\mathrm{pH} 8.0,1 \%$ PVP (polyvinylpyrrolidone) 10, 1\% PEG (polyethylene glycol) 6000 and $10 \mathrm{mM}$ 2-mercaptoethanol.

2. Carborundum powder $(0.013 \mathrm{~mm})$.

3. Cotton swabs.

All of the materials required are the same as Subheading 2.1.

1. Syn-tasiRNA vectors: $p E N T R-A t T A S 1 c-B / c$ (Addgene plasmid 51774), $p M D C 123 S B-A t T A S 1 c-B / c$ (Addgene plasmid 51772 ) and $p M D C 32 B-A t T A S 1 c-B / c$ (Addgene plasmid 51773) (Table 1).

2. Other reagents listed in Subheading 2.2.

All of the materials required are the same as Subheading 2.3.

\section{Methods}

The main steps regarding the design, synthesis, and analysis of antiviral artificial sRNAs are summarized in Fig. 1.

\subsection{Antiviral AmiRNA Design}

1. Download the virus sequences (e.g., from NCBI).

2. Go to P-SAMS amiRNA Designer website (http://p-sams. carringtonlab.org/amirna/designer). 


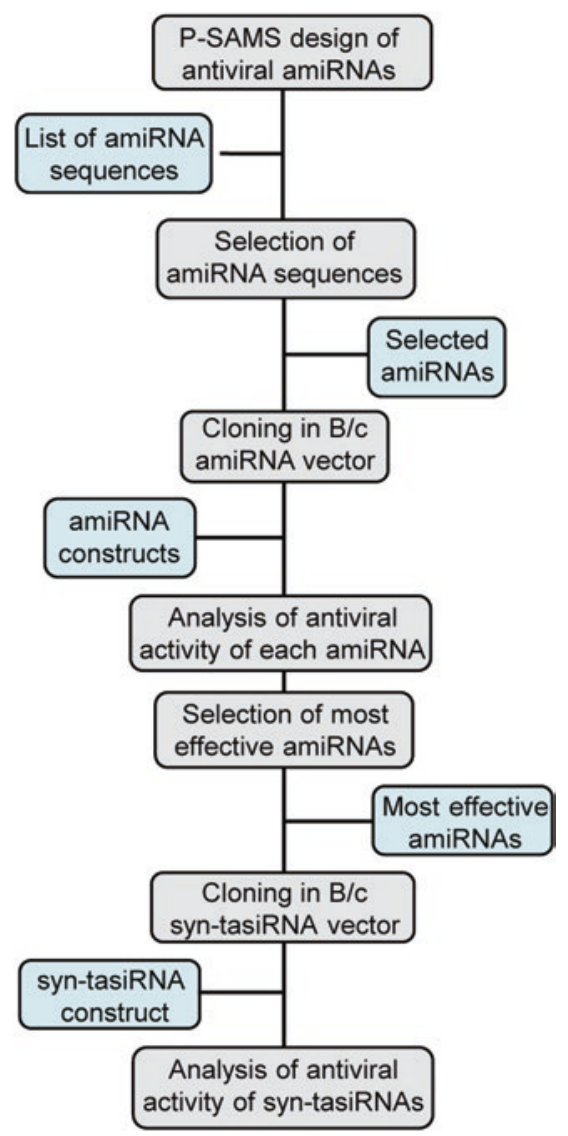

Fig. 1 Diagram of the steps for the design and synthesis of antiviral amiRNAs and syn-tasiRNAs, and for the analysis of their antiviral activity. Each step is described in light grey boxes. The product of each step is shown in light blue boxes

3. Click "Get Started" and then "Design an amiRNA" to start the design process.

4. Select the transcriptome of the species of interest and click "Yes."

5. Click "Option 2" to target an exogenous transcript such as a viral RNA.

6. Enter or paste the FASTA sequence(s) of target viral RNA(s) and click "Next" ( see Note 3).

7. Click "Yes" to have the results automatically filtered based on target specificity ( see Note 4 ).

8. Click "Submit" to submit the job.

9. Select "Click to see Results" to display the results. AmiRNAs predicted to target uniquely viral RNA(s) are output as "Optimal Results"; amiRNAs predicted to target viral RNA(s) and endogenous transcripts are output as "Sub-optimal Results." 
3.2 Antiviral AmiRNA Cloning

\subsection{Functional} Analysis of Antiviral AmiRNAs

3.3.1 Experimental Setup
10. Click "Download" to download the result summary including a list of amiRNA sequences together with the sequence of the two oligonucleotides required for cloning each amiRNA insert in compatible amiRNA B/c vectors (Table 1 ).

1. Resuspend the two oligonucleotides in sterile $\mathrm{H}_{2} \mathrm{O}$ to a final concentration of $100 \mu \mathrm{M}$.

2. Assemble the oligonucleotide annealing reaction in a PCR tube as follows: $2 \mu \mathrm{L}$ of $100 \mu \mathrm{M}$ forward oligonucleotide, $2 \mu \mathrm{L}$ of $100 \mu \mathrm{M}$ reverse oligonucleotide and $46 \mu \mathrm{L}$ of oligo annealing buffer.

3. Transfer the tube to a thermocycler set to heat the annealing reaction $5 \mathrm{~min}$ at $94{ }^{\circ} \mathrm{C}$ and then cool down to $20{ }^{\circ} \mathrm{C}$ at a rate of $0.05{ }^{\circ} \mathrm{C} / \mathrm{s}$ ( see Note 5 ).

4. Dilute the annealed oligonucleotides to a final concentration of $0.15 \mu \mathrm{M}$ by mixing $3 \mu \mathrm{L}$ annealed oligonucleotides and $37 \mu \mathrm{L} \mathrm{H}_{2} \mathrm{O}$ (see Note 6).

5. Assemble the digestion-ligation reaction as follows: $50 \mathrm{ng}$ $\mathrm{B} / \mathrm{c}$ vector, $1 \mu \mathrm{L}$ diluted annealed oligonucleotides, $1 \mu \mathrm{L} 10 \times$ T4 DNA ligase buffer, $1 \mu \mathrm{L}$ of $5 \mathrm{U} / \mu \mathrm{L}$ T4 DNA ligase, $1 \mu \mathrm{L}$ of $10 \mathrm{U} / \mu \mathrm{L}$ BsaI and add sterile $\mathrm{H}_{2} \mathrm{O}$ to $10 \mu \mathrm{L}$. Use the amiRNA B/c vector of your choice (Table 1) (see Note 7).

6. Mix the reactions by pipetting and incubate for $5 \mathrm{~min}$ at $37^{\circ} \mathrm{C}$.

7. Transform 1-5 $\mathrm{L}$ of the digestion-ligation product into a $c c d \mathrm{~B}$-sensitive E. coli strain and plate on an LB agar plate with kanamycin.

8. Pick two colonies per construct, grow in $4 \mathrm{~mL}$ of liquid LB with kanamycin and purify plasmids with a miniprep kit.

9. Sequence two clones per construct with appropriate oligonucleotides: M13-F and M13-R for $p E N T R$-based vectors, att-

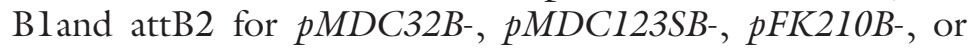
pH7WG2B-based vectors.

10. Transform $0.5 \mu \mathrm{L}$ of the purified plasmid into $A$. tumefaciens GV3101. Plate 1/10 of the culture in a LB agar plate including rifampicin and kanamycin.

11. Incubate the plate at $28^{\circ} \mathrm{C}$ during $48 \mathrm{~h}$.

12. Store the plate with grown colonies at $4{ }^{\circ} \mathrm{C}$ until use.

The main steps of the experimental plan for the functional analysis of antiviral amiRNAs are summarized in Fig. 2 and described below. Typically, three blocks (A, B, and C) of three plants are required for the functional analysis of each antiviral amiRNA construct. It is highly recommended to compare the activity of 


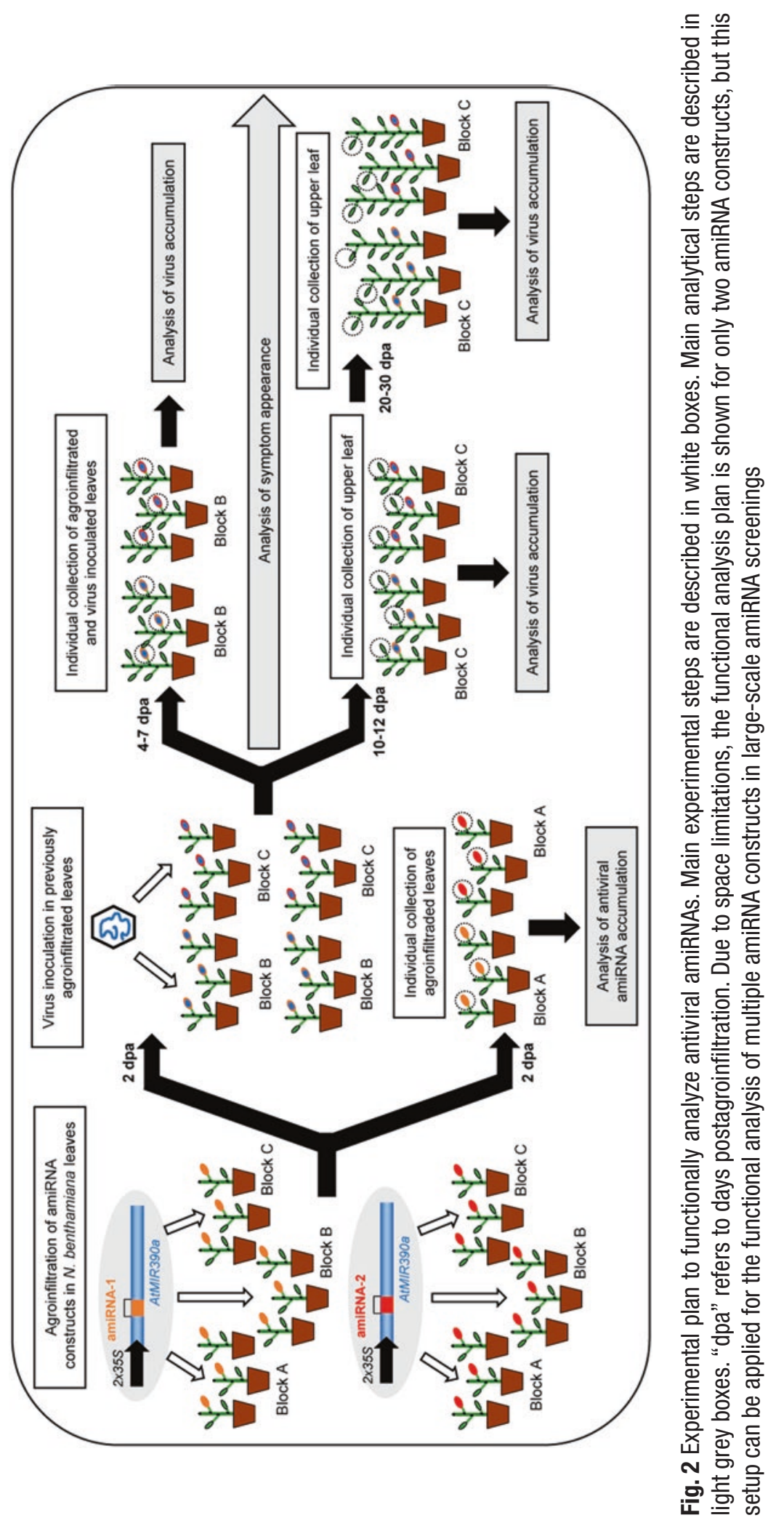




\subsubsection{Agroinfiltration of $\mathrm{N}$. benthamiana Leaves with Antiviral AmiRNA Constructs}

antiviral amiRNAs with a control amiRNA targeting an exogenous sequence other than the viral RNA (E. coli $\beta$-glucuronidase (GUS), green fluorescent protein (GFP), etc.) ( see Note 8).

1. For each amiRNA construct to be analyzed, pick a single colony of $A$. tumefaciens transformed with the corresponding construct using a toothpick.

2. Transfer to a culture tube that contains $5 \mathrm{~mL}$ of $\mathrm{LB}$ with rifampicin and kanamycin.

3. Incubate the starter culture at $28{ }^{\circ} \mathrm{C}$ for $24 \mathrm{~h}$ on a shaking incubator.

4. Transfer $1-5 \mathrm{~mL}$ of the starter culture to $50 \mathrm{~mL}$ of $\mathrm{LB}$ containing kanamycin in a $250 \mathrm{~mL}$ flask.

5. Shake for $4-6 \mathrm{~h}$ at $28{ }^{\circ} \mathrm{C}$ until $\mathrm{OD}_{600} \sim 0.55$.

6. Centrifuge $45 \mathrm{~mL}$ of culture for $15 \mathrm{~min}$ at $5000 \times g$ in a $50 \mathrm{~mL}$ conical tube.

7. Remove the supernatant and resuspend in equal volume of Vir Induction medium.

8. Transfer back to flasks and shake overnight $(\sim 14 \mathrm{~h})$ at $28^{\circ} \mathrm{C}$.

9. Measure $\mathrm{OD}_{600}$ of the overnight culture.

10. Calculate the volume of Infiltration solution to resuspend the pellet to an $\mathrm{OD}_{600} \sim 1.1$.

11. Centrifuge the culture for $15 \mathrm{~min}$ at $5000 \times g$ in a $50 \mathrm{~mL}$ conical tube.

12. Remove the supernatant and resuspend pellet in calculated volume of Infiltration solution.

13. Measure $\mathrm{OD}_{600}$, and normalize the culture to a final $\mathrm{OD}_{600}$ of 1.0 .

14. Mix the amiRNA culture with an equal volume of a $A$. tumefaciens culture including an empty vector or control construct such as $p M D C 32-G U S$ [17].

15. Infiltrate the whole abaxial surface of the fourth emerged leaf of nine 3-4-week-old N. benthamiana plants (Fig. 2).

16. Two days postagroinfiltration ( $\mathrm{dpa}$ ), collect independently the infiltrated leaf of each of the three plants of block A (Fig. 2). Store tissue at $-80{ }^{\circ} \mathrm{C}$ until needed.

3.3.3 Analysis of Antiviral AmiRNA Accumulation

Total RNA Extraction
This step is recommended to confirm that amiRNAs are being expressed in planta.

1. Place frozen leaf in a labeled mortar and pour $30-50 \mathrm{~mL}$ liquid nitrogen.

2. Lightly crush leaves after liquid nitrogen has completely evaporated; grind vigorously until tissue is powdered. 
3. Add $5 \mathrm{~mL}$ of TRIzol and continue homogenization to mix partially frozen sample.

4. Transfer homogenized sample to a $15 \mathrm{~mL}$ conical tube.

5. Centrifuge at $7000 \times g$ for $10 \mathrm{~min}$ at $4{ }^{\circ} \mathrm{C}$ to pellet cell debris.

6. Transfer supernatant to a new $15 \mathrm{~mL}$ conical tube.

7. Add $3 \mathrm{~mL}$ of chloroform and shake vigorously for $20 \mathrm{~s}$.

8. Incubate at room temperature for $3 \mathrm{~min}$.

9. Centrifuge at $7000 \times g$ for $10 \mathrm{~min}$ at $4^{\circ} \mathrm{C}$ to separate phases.

10. Transfer aqueous phase to new $15 \mathrm{~mL}$ conical tube.

11. Add $5 \mathrm{~mL}$ cold isopropanol.

12. Invert several times and incubate for $10 \mathrm{~min}$ at room temperature.

13. Centrifuge at $10,000 \times g$ for $10 \mathrm{~min}$ at $4^{\circ} \mathrm{C}$ to pellet RNA.

14. Wash the pellet with cold $75 \%$ ethanol by adding the ethanol, inverting twice and pouring off.

15. Air-dry for $2 \mathrm{~min}$ and remove residual ethanol by pipetting.

16. Air-dry for $2 \mathrm{~min}$ and resuspend the pellet in 100-200 $\mu \mathrm{L}$ sterile $\mathrm{H}_{2} \mathrm{O}$.

17. Transfer to a $1.5 \mathrm{~mL}$ microcentrifuge tube.

18. Quantify RNA concentration with a NanoDrop.

Northern Blot Analysis of AmiRNAs
Confirm the accumulation of amiRNA in planta by Northern blot hybridization following standard protocols. The following are some specifications.

1. Prepare a $17 \%$ polyacrylamide gel containing $7 \mathrm{M}$ Urea in $0.5 \times$ TBE. Mix $17 \mathrm{~mL}$ of $30 \%$ polyacrylamide (acrylamide-bisacrylamide, 37.5:1), $12.6 \mathrm{~g}$ of urea, $1.5 \mathrm{~mL}$ of $5 \times \mathrm{TBE}$, and $2 \mathrm{~mL}$ $\mathrm{H}_{2} \mathrm{O}$. Mix thoroughly by inversion. Do not shake or vortex as this incorporates oxygen to the solution which inhibits polymerization. Heat to $65^{\circ} \mathrm{C}$ for $10 \mathrm{~min}$ to dissolve the urea. Stir for additional $5 \mathrm{~min}$ on the bench to allow final resuspension of urea, and keep $20 \mathrm{~min}$ on ice to chill the solution. Add $25 \mu \mathrm{L}$ TEMED and mix by inversion. Add $150 \mu \mathrm{L}$ of $10 \%$ ammonium persulfate and mix quickly by inversion. Pour the gel and allow it to polymerize for at least $30 \mathrm{~min}$.

2. Prerun the gel at $180 \mathrm{~V}$ in $0.5 \times \mathrm{TBE}$ for $1 \mathrm{~h}$. Rinse wells before loading samples as urea accumulates at the bottom of the wells.

3. Add an equal amount of formamide loading buffer to the total RNA. Heat the samples for $10 \mathrm{~min}$ at $65^{\circ} \mathrm{C}$ and immediately quench on ice briefly.

4. Load $10-20 \mu \mathrm{g}$ of total RNA. Run at $180 \mathrm{~V}$ in $0.5 \times$ TBE until the bromophenol blue reaches the bottom of the gel $(\sim 4 \mathrm{~h})$. 
5. Assemble the blot sandwich with blotting paper (three sheets, prewetted with $0.5 \times \mathrm{TBE}$ ), gel, a sheet of positively charged nylon membrane, and another three sheets of blotting paper prewetted with $0.5 \times \mathrm{TBE}$ in a semidry chamber. Transfer for $30 \mathrm{~min}$ at $1 \mathrm{~mA}$ per $\mathrm{cm}^{2}$ of membrane. Cross-link RNA to the membrane at $0.12 \mathrm{~J} / \mathrm{cm}^{2}$ using a UV cross-linker. Store membranes between two sheets of filter paper until use.

6. Prepare the following reaction mix to radiolabel the probe oligonucleotide (see Note 9): $1 \mu \mathrm{L} 10 \mu \mathrm{M}$ probe oligonucleotide, $1 \mu \mathrm{L} 10 \times$ polynucleotide kinase buffer, $3 \mu \mathrm{L}$ sterile $\mathrm{H}_{2} \mathrm{O}, 4 \mu \mathrm{L}\left[{ }^{32} \mathrm{P}\right] \gamma$-ATP $(6000 \mathrm{Ci} / \mathrm{mmol} ; 10 \mathrm{mCi} / \mathrm{mL})$, and $1 \mu \mathrm{L} \mathrm{T} 4$ polynucleotide kinase.

7. Incubate for $60 \mathrm{~min}$ at $37^{\circ} \mathrm{C}$. Purify probe on spin columns according to manufacturer's instructions. Quantify the incorporated radioactivity $(\mathrm{CPM} / \mu \mathrm{L})$.

8. Place the membrane (RNA-side-up) in a hybridization tube and prehybridize with rotation for at least $5 \mathrm{~min}$ at $38-42{ }^{\circ} \mathrm{C}$ (see Note 10) in $5 \mathrm{~mL}$ of hybridization buffer.

9. Mix 1,000,000-2,000,000 CPM of probe with $200 \mu \mathrm{L}$ of PerfectHyb ${ }^{\mathrm{TM}}$ Plus buffer, incubate for $2 \mathrm{~min}$ at $95{ }^{\circ} \mathrm{C}$, and transfer immediately to ice briefly.

10. Replace the hybridization solution, add the probe to the hybridization tube and incubate for $12-16$ h at $38-42{ }^{\circ} \mathrm{C}$ (see Note 10).

11. Remove hybridization solution and wash the membrane five times with preheated wash solutions as follows: wash buffer 1 thorough rinse, wash buffer 1 for $5 \mathrm{~min}$ with rotation at $38-42^{\circ} \mathrm{C}$, wash buffer 1 for $20 \mathrm{~min}$ with rotation at $55^{\circ} \mathrm{C}$, wash buffer 1 for $20 \mathrm{~min}$ with rotation at $55^{\circ} \mathrm{C}$, wash buffer 2 for 20 min with rotation at $55^{\circ} \mathrm{C}$, and wash buffer 2 for $30 \mathrm{~min}$ with rotation at $55^{\circ} \mathrm{C}($ see Note 11$)$.

12. Rinse membrane briefly in $3 \times$ SSC, then air-dry briefly and cover in transparent plastic wrap.

\section{Autoradiograph.}

The mechanical inoculation of plants from blocks $\mathrm{B}$ and $\mathrm{C}$ is described next.

1. From a previously obtained virus infected tissue, prepare a crude extract in 20 volumes of Inoculation buffer.

2. Deposit several drops ( $5 \mu \mathrm{L}$ each) of $10 \%$ carborundum in Inoculation buffer on leaf surface. Note that the number of drops will depend on the leaf size, although one or two drops per leave should be enough.

3. Dip a cotton swab in the tube containing the infected-plant extract. 


\subsubsection{Analysis of Symptom Appearance}

3.3.6 Analysis of Virus Accumulation

\subsection{Antiviral Syn-tasiRNA Design}

\subsection{Antiviral Syn-tasiRNA Cloning}

\subsection{Functional Analysis of Antiviral Syn-tasiRNA}

4. Apply the extract to the whole surface of the leaf that was previously agroinfiltrated 2 days before with the artificial sRNA construct (Fig. 2) ( see Note 12).

After virus inoculation, plants must be monitored for viral symptoms appearance (Fig. 2). Depending on the virus, symptoms can appear on inoculated and/or upper noninoculated tissue. The day of symptom appearance in either tissue must be annotated.

Virus presence or absence can be determined through different types of assays including ELISA, Western blot, Northern blot, or quantitative RT-PCR (see Note 13). Two time points are recommended for virus detection: (1) an early time point a few days after the controls show viral symptoms in upper noninoculated tissues (e.g., 10-12 dpa if symptoms appear 7-9 dpa in controls), and (2) a late time point $(20-30 \mathrm{dpa})$ to analyze if the plant is definitely free of virus close to the end of its life cycle (Fig. 2). Note that dpa time is always 2 days ahead of virus inoculation.

1. Select 2-5 amiRNA sequences with high antiviral activity based on the amiRNA functional analysis described above (see Subheading 3.3). These sequences will be expressed as syn-tasiRNAs in a single construct.

2. Go to P-SAMS syn-tasiRNA Designer website (http://p-sams. carringtonlab.org/syntasi/designer) [15].

3. Click "Get Started" to start the design process.

4. Click "Generate Oligos."

5. Enter 2-5 syn-tasiRNA sequences.

6. Click "Submit" to submit the job.

7. Select "Click to see Results" to display results.

8. Click "Download" to download the sequence of the syntasiRNAs and the sequence of the two oligonucleotides required for cloning the syn-tasiRNA cassette in compatible syn-tasiRNA B/c vectors (Table 1 ).

Follow the steps described in Subheading 3.2 using the syn-tasiRNA vector of your choice (Table 1 ).

Follow the experimental plan described in Fig. 2 to functionally analyze the antiviral activity of the antiviral syn-tasiRNA construct. As noted for the antiviral amiRNA functional analysis (see Subheading 3.3.1), it is highly recommended to compare the activity of the antiviral syn-tasiRNA construct with a control syn-tasiRNA including several syn-tasiRNA sequences targeting an artificial transcript (e.g. GUS, GFP, etc.) (see Note 14). 


\section{Notes}

1. Prepare Oligo Annealing Buffer, make $1 \mathrm{~mL}$ aliquots and store at $-20{ }^{\circ} \mathrm{C}$.

2. B/c vectors must be ordered at Addgene website (http:// www.addgene.org/).

3. Multiple viral sequences can be entered, for example, when several sequence variants of the same virus are required to be targeted simultaneously.

4. This option allows the design of specific amiRNAs that will exclusively target viral RNA(s) without affecting endogenous transcripts.

5. Alternatively, the annealing reaction can be done in a water bath or thermoblock by heating during $5 \mathrm{~min}$ at $94{ }^{\circ} \mathrm{C}$ and then turning off the apparatus. Let the reaction to cool down until it reaches room temperature.

6. Do not store the diluted oligonucleotides.

7. If amiRNA inserts are cloned in $p E N T R$-based $\mathrm{B} / \mathrm{c}$ vectors, then the amiRNA cassette can be transfer through GATEWAY recombination to a destination vector such as pMDC32 or pMDC99.

8. As for antiviral amiRNAs, use P-SAMS amiRNA Designer to design a highly specific amiRNA targeting an exogenous sequence other than the viral RNA. Confirm that the selected amiRNA does not extensively base pair with viral RNA(s) to avoid undesired silencing of the virus.

9. Oligonucleotide sequence is antisense to the artificial sRNA that is analyzed. Start by using a DNA probe for artificial sRNA detection as DNA oligonucleotides are cheap and work well most of the times. However, if sRNA detection with a DNA probe fails then use an LNA probe. Order the LNA oligonucleotide with every other three nucleotides locked, including the first one (e.g., an LNA probe to detect A. thaliana miR172 is $\mathrm{A}+\mathrm{TGC}+\mathrm{AGC}+\mathrm{ATC}+\mathrm{ATC}+\mathrm{AAG}+\mathrm{ATT}+\mathrm{CT}$, where the + indicates the locked nucleotide).

10. If using an LNA probe prehybridize and hybridize at $\sim 20{ }^{\circ} \mathrm{C}$ below the calculated dissociation temperature $\left(\mathrm{T}_{\mathrm{d}}\right)\left[\mathrm{T}_{\mathrm{d}}\right.$ $\left.\left({ }^{\circ} \mathrm{C}\right)=4(\mathrm{G}+\mathrm{C})+2(\mathrm{~A}+\mathrm{T})\right]$ for the corresponding ${ }^{32} \mathrm{P}$-labeled oligonucleotide.

11. This works in the majority of cases. If there is still a background problem, proceed to an additional incubation of the membrane with $0.1 \times \mathrm{SSC} / 0.1 \% \mathrm{SDS}$ for $60 \mathrm{~min}$ at $50{ }^{\circ} \mathrm{C}$, or with $0.1 \times \mathrm{SSC} / 1 \% \mathrm{SDS}$ for $60 \mathrm{~min}$ at $50{ }^{\circ} \mathrm{C}$.

12. Use the cotton swab as a pencil to gently "paint" the whole surface of the leaf. 
13. The choice of a particular assay will depend on the virus to be detected. For instance, ELISA has been optimized for Tomato spotted wilt virus detection [18].

14. The control syn-tasiRNA construct can be designed using P-SAMS syn-tasiRNA Designer (http://p-sams.carringtonlab.org/syntasi/designer).

\section{Acknowledgments}

This work was supported by grants from Ministerio de Ciencia, Innovación y Universidades (MCIU, Spain), Agencia Estatal de Investigación (AEI, Spain) and Fondo Europeo de Desarrollo Regional (FEDER, European Union) [RTI2018-095118-A-100 and RYC-2017-21648 to A.C.; BIO2017-83184-R to J.-A.D.].

\section{References}

1. Carbonell A (2017) Artificial small RNA-based strategies for effective and specific gene silencing in plants. In: Dalmay T (ed) Plant gene silencing: mechanisms and applications. CABI Publishing, Boston, MA, pp 110-127

2. Carbonell A (2017) Plant ARGONAUTEs: features, functions, and unknowns. Methods Mol Biol 1640:1-21. https://doi. org/10.1007/978-1-4939-7165-7_1

3. Niu QW, Lin SS, Reyes JL, Chen KC, Wu HW, Yeh SD, Chua NH (2006) Expression of artificial microRNAs in transgenic Arabidopsis thaliana confers virus resistance. Nat Biotechnol 24(11):1420-1428. https://doi. org/10.1038/nbtl255

4. Lin SS, Wu HW, Elena SF, Chen KC, Niu QW, Yeh SD, Chen CC, Chua NH (2009) Molecular evolution of a viral non-coding sequence under the selective pressure of amiRNA-mediated silencing. PLoS Pathog 5(2):e1000312. https://doi.org/10.1371/journal.ppat. 1000312

5. Lafforgue G, Martinez F, Sardanyes J, de la Iglesia F, Niu QW, Lin SS, Sole RV, Chua NH, Daros JA, Elena SF (2011) Tempo and mode of plant RNA virus escape from RNA interference-mediated resistance. J Virol 85(19):96869695.

JVI.05326-11

https://doi.org/10.1128/

6. Fahim M, Millar AA, Wood CC, Larkin PJ (2012) Resistance to Wheat streak mosaic virus generated by expression of an artificial polycistronic microRNA in wheat. Plant Biotechnol J 10(2):150-163. https://doi.org/10.1111/j. 1467-7652.2011.00647.x
7. Kung YJ, Lin SS, Huang YL, Chen TC, Harish SS, Chua NH, Yeh SD (2012) Multiple artificial microRNAs targeting conserved motifs of the replicase gene confer robust transgenic resistance to negative-sense single-stranded RNA plant virus. Mol Plant Pathol 13(3):303-317. https:// doi.org/10.1111/j.1364-3703.2011.00747.x

8. Lafforgue G, Martinez F, Niu QW, Chua NH, Daros JA, Elena SF (2013) Improving the effectiveness of artificial microRNA (amiR)mediated resistance against Turnip mosaic virus by combining two amiRs or by targeting highly conserved viral genomic regions. J Virol 87(14):8254-8256. https://doi.org/10. 1128/JVI.00914-13

9. Kis A, Tholt G, Ivanics M, Varallyay E, Jenes B, Havelda Z (2016) Polycistronic artificial miRNA-mediated resistance to Wheat dwarf virus in barley is highly efficient at low temperature. Mol Plant Pathol 17(3):427-437. https://doi.org/10.1111/mpp.12291

10. Carbonell A, Carrington JC, Daros JA (2016) Fast-forward generation of effective artificial small RNAs for enhanced antiviral defense in plants. RNA Dis 3(1)

11. Chen L, Cheng X, Cai J, Zhan L, Wu X, Liu Q, Wu X (2016) Multiple virus resistance using artificial trans-acting siRNAs. J Virol Methods 228:16-20. https://doi.org/10.1016/j. jviromet.2015.11.004

12. Carbonell A, Daros JA (2017) Artificial microRNAs and synthetic trans-acting small interfering RNAs interfere with viroid infection. Mol Plant Pathol 18(5):746-753. https://doi. org/10.1111/mpp.12529 
13. Carbonell A, Takeda A, Fahlgren N, Johnson SC, Cuperus JT, Carrington JC (2014) New generation of artificial MicroRNA and synthetic trans-acting small interfering RNA vectors for efficient gene silencing in Arabidopsis. Plant Physiol 165(1):15-29. https://doi. org/10.1104/pp.113.234989

14. Carbonell A, Fahlgren N, Mitchell S, Cox KL Jr, Reilly KC, Mockler TC, Carrington JC (2015) Highly specific gene silencing in a monocot species by artificial microRNAs derived from chimeric miRNA precursors. Plant J 82(6):1061-1075. https://doi. org/10.1111/tpj.12835

15. Fahlgren N, Hill ST, Carrington JC, Carbonell A (2016) P-SAMS: a web site for plant artificial microRNA and synthetic trans-acting small interfering RNA design. Bioinformatics 32(1):157-158. https://doi.org/10.1093/ bioinformatics/btv534
16. Carbonell A, López C, Daròs JA (2019) Fastforward identification of highly effective artificial small RNAs against different Tomato spotted wilt virus isolates. Mol Plant-Microbe Interact 32(2):142-156. https://doi.org/10. 1094/MPMI-05-18-0117-TA

17. Montgomery TA, Howell MD, Cuperus JT, Li D, Hansen JE, Alexander AL, Chapman EJ, Fahlgren N, Allen E, Carrington JC (2008) Specificity of ARGONAUTE7-miR390 interaction and dual functionality in TAS3 trans-acting siRNA formation. Cell 133(1):128-141. https://doi.org/10.1016/j.cell.2008.02.033

18. Mitter N, Zhai Y, Bai AX, Chua K, Eid S, Constantin M, Mitchell R, Pappu HR (2016) Evaluation and identification of candidate genes for artificial microRNA-mediated resistance to tomato spotted wilt virus. Virus Res 211:151-158. https://doi.org/10.1016/j. virusres.2015.10.003 